$$
\begin{aligned}
& \text { بروسى تأثيرات عصاره هيدروالكلى زياه تزنه بر فاكتورهاى التهابى كبلى رتهاى ويستار مبتلا به }
\end{aligned}
$$

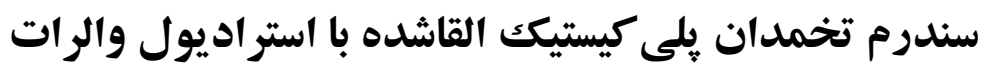

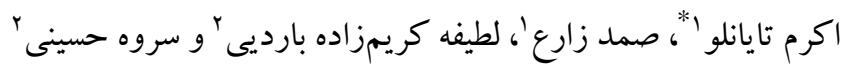

$$
\begin{aligned}
& \text { دريافت: } \\
& \text { 'خروه زيستشناسى جانورى، دانشكدة علوميايه، دانشخاه اروميه، اروميه، ايران }
\end{aligned}
$$

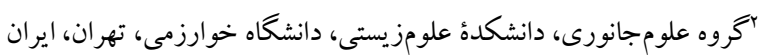

$$
\begin{aligned}
& \text { "مسئول مكاتبات: a.tayanloo@gmail.com }
\end{aligned}
$$

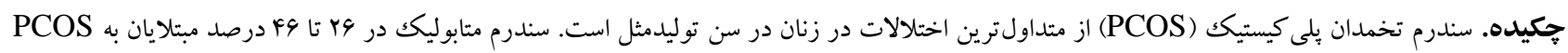

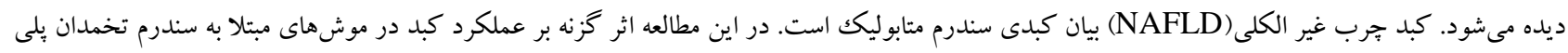

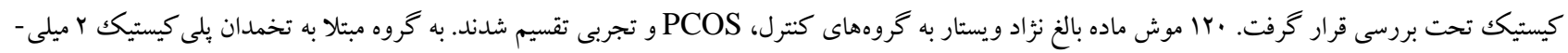

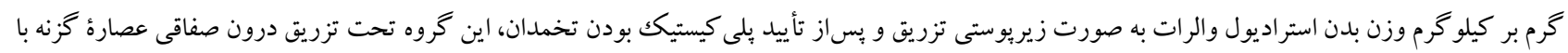

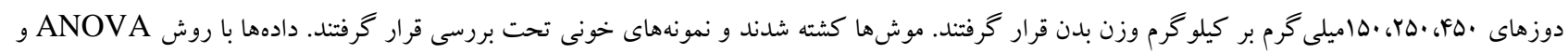

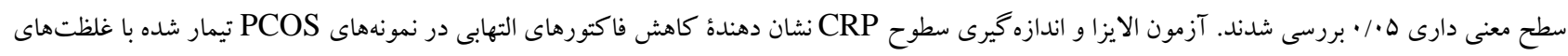

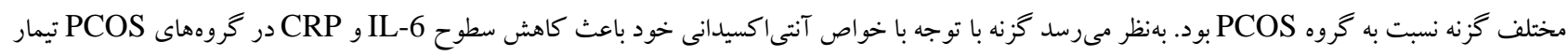

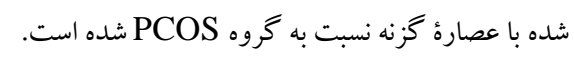
وازههاى كليدى. كبد جرب، التهاب، تخمدان، الايزا

\title{
Effect of Urtica dioica hydroalcoholic extract on liver inflammatory factors in polycystic ovarian syndrome induced in Wistar rats by estradiol valerate
}

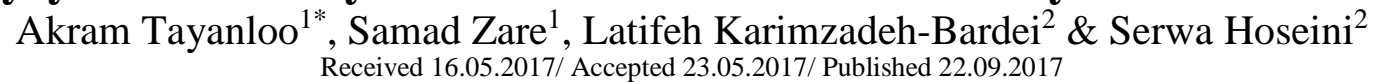

${ }^{1}$ Department of Biological Sciences, Urmia University, Urmia, Iran

${ }^{2}$ Department of Animal Biology, Faculty of Biological Sciences, Kharazmi University, Tehran, Iran

*Correspondent author: a.tayanloo@gmail.com

\begin{abstract}
The polycystic ovary syndrome (PCOS) is one of the most common endocrine disorders in women at childbearing age. Metabolic syndrome is present from $28 \%$ to $46 \%$ of patients with PCOS. Non-alcoholic fatty liver disease (NAFLD) is considered the hepatic expression of metabolic syndrome. In this study Urtica dioica moderator effect on liver function in PCOS rats was examined. 120 adult female Wistar rats were divided into control, PCOS and nettle-treated groups. The PCOS group was injected subcutaneously $2 \mathrm{mg} / \mathrm{kg}$ estradiol valerate. After confirmed polycystic in ovaries, the experimental group was injected of the nettle extract doses (150,250, $450 \mathrm{mg} / \mathrm{kg}$ BW). Then rats were killed and blood samples were evaluated. Data were analyzed using ANOVA one-way and $\mathrm{p}<0.05$ was considered statistically significant. ELISA test showed a decrease in IL-6 level and CRP levels reduced in PCOS rats were treated with various concentrations of nettle. Our results show that nettle due to its antioxidant properties reduce the levels of IL-6 and CRP in nettle extract treated-PCOS compared to the PCOS.
\end{abstract}

Keywords. fatty liver, inflammation, ovary, ELISA 
Chang et al., توسط انواع مختلفى از سلولها از جمله سلولهاى كبدى ترشح مىشوند (Tracey et al., 1993). سيتوكينها از جندين زيرخانواده تشكيل شدهاند كه شامل اينترلوكينها، فاكتورهاى نكروز تومورى (TNF)، اينترفرونها و غيره هستند. سيتو كين ها كه يكى از انواع آنها است جندين فرايند بيولوزيكى اساسى را IL-6 در بدن ميانجى گرى مى كنند كه از جمله آنها التهاب است (Miller et al., 2011). IL-6 آثار مختلفى در بخشى هاى كوناكون بدن دارد، ولى بيشترين تأثير خود را از طريق اثر بر حساسيت به انسولين اعمال مى كند (Klover et al., 2005). از آنجايى كه مقاومت به انسولين از اصلىترين علل بروز PCOS و در نتيجه آن ايجاد NAFLD است، استفاده از تركيباتى كه داراى خو اص ضد التهابى است و در نتيجه موجب كاهش سطوح IL-6 در بدن مى شوند مى تواند در تخفيف علائم مربوط به NAFLD مؤثر واقع شود.

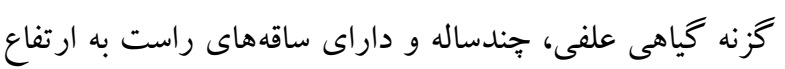

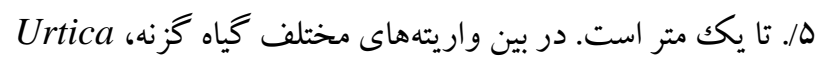
Urtica urens و بهنزلة كياهان دارويى از زمانهاى dioica Janbakhsh et al., ) بسيار دور دركانون توجه قرار داشتهاند 2013). عصاره گزنه داراى تر كيباتى از قبيل اسيدهاى جرب إن از جمله اسيدآلفالينوئيك و همجينين كاروتنوئيدها مثل ايزومرهاى لوتئين و ايزومرهاى بتاكاروتن و ليكوين، فنولها مثل اسيد فروليك، اسيد گاليك، اسيدسينرزيك،، فلاونوئيدها مثل كاتجين و ايى كاتجين و تركيبات ديخر شامل نئو گزاتين و ويلو گز انتين است - (Monfared et al., 2013) اكسيدانى، ضدالتهابى، اتساع رگى،، كاهشدهندهُ جربى خون و كاهشدهندهُ قند خون است (James, 2008). با توجه به تركيبات و خواص اين كياه انتظار مىرود كه استفاده از آن تأثيراتى در كاهش سطوح فاكتورهاى التهابى و در نتيجه كاهش آثار حاصل از اين عوامل از جمله مقاومت به انسولين داشته باشد.

\section{مواد و روشها - (- ماد}

در اين مطالعه تجربى كه در سال سوها دور دانشكاه خوارزمى

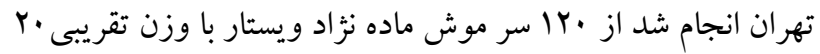

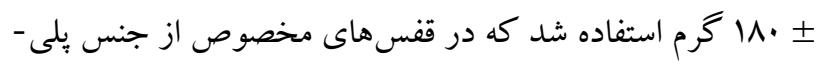

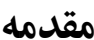

سندرم تخمدان يلى كيستيك (PCOS) يكى از اختلالات

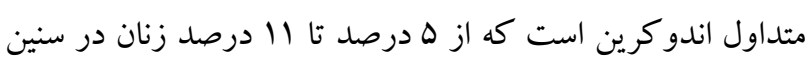
Apridonidze et al., ) توليدمثل را تحت تأثير قرار مىدهد .(2005; Azziz et al., 2006; Dokras et al., 2005 معمولاً با سيكلهاى نامنظم قاعدگى (اليگومنوره) و PCOS

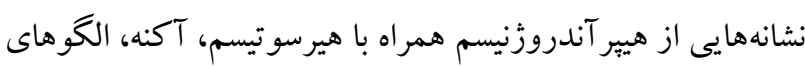
افزايش يافته آندروزنى همراه است. انسولين نقشهاى مستقيم و غيرمستقيمى را در پاتوزنز هايِراندروزنيسم در زنان مبتلا به ايفا مى كند كه بهصورت سينرزيكك با هورمون لوتئنى PCOS عمل مى كند و باعث افز ايش سنتز آندروزنها توسط سلول- (LH) هاى تكاى تخمدان مىشود. به علاوه، انسولين باعث مهار هورمون متصل شونده به استروئيدها (SHBG) توسط كبد مىشود كه در نتيجه مقادير تستوسترون آزاد در گردش خون افزايش ييدا مى كند. از آنجايى كه مبتلايان به PCOS معمولاً دجار هيبر انسولينميا هستند، غلظت تستوسترون آزاد در خون افزايش مى يابد، حتى اكر Azziz et al., ) مقادير كلى تستوسترون بالاتر از حد نرمال باشد 2006). به دليل اينكه مقاومت به انسولين يكى از عوامل پيايه سندرم متابوليكك است، درمبتلايان به PCOS و سطوح بالاى انسولين يلاسمايى عامل خطر درخورتوجهى براى ايجاد عوارض متابوليك و قلبى عروقى ازقبيل جاقى، عدم تحمل كلو كز و ديابت نوع كا، ديس لبيدميا و بيمارىهاى قلبى است ( Srikanthan et al., 2006 ). در واقع، درجندين تحقيق به فراوانى بيشتر سندرم متابوليك (MS) و بعضى از اجزاى آن به تنهايى در زنان مبتلا به

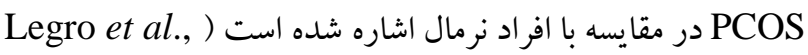
(1999; Carmina et al., 2006 همانند آنجه در PCOS و اتفاق مىافتد، مقاومت به انسولين همجِنين در پِاتوزنز كبد جرب غير الكلى (NAFLD)، از متداولترين نوع بيمارىهاى (Brzozowska et al., كبدى عصر حاضر، بهشمار مى آيد (2009. بنابراين بيماران مقاوم به انسولين استعداد بيشترى براى ابتلا به NAFLD دارند. كبد جرب غير الكلى و سندرم تخمدان يلى كيستيك هر دو در ارتباط با سندرم متابوليكك هستند كه با جاقى، هايير تانسيون، ديابت نوع r و ديس ليبيدميا مشخص مىشود. به نظر مىرسد سازوكار بِاتوفيزيولوزيكك شايع، كه در هر دو اين اختلالات به جشم مى خورد، مقاومت به انسولين است (1983 
سه كروه از موش هاى PCOS به ترتيب تحت تزريق درون-

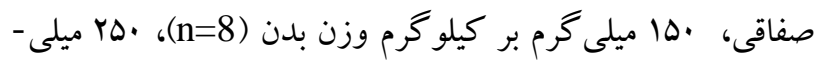

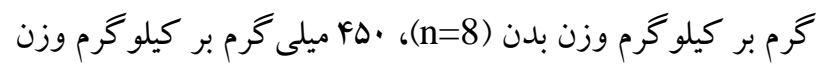

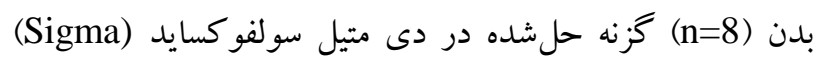
قرار گرفتند. به منظور بررسى اثر حلال گزنه يك گرووه نيز با عنوان گرووه شاهد تحت تزريق حجم مشابهى از دىمتيل

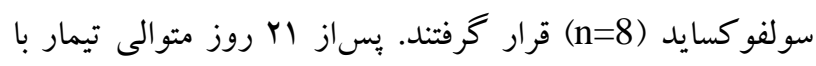
كزنه موشها با تنفس كلروفرم كشته شدند و بخشى از لوب راست كبد آنها برداشته شد و در محلول بوئن الكلى فيكس شد. نمونههاى بافتى توسط محلول اتانول صعودى آبخيرى شد و يساز

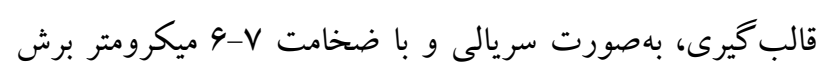

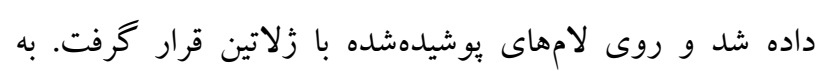
منظور بررسى هيستومورفومتريك،، برشها بس از بارافينزدايى و آبدهى توسط محلولهاى الكل با درجات نزولى، با روش

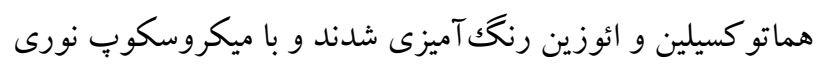
مورد بررسى قرار كرفتند. جمعاً تعداد ·r مقطع از مقاطع تهيهشده از بافت كبد در هر گرووه تحت مطالعه قرار گرفت. بدين ترتيب

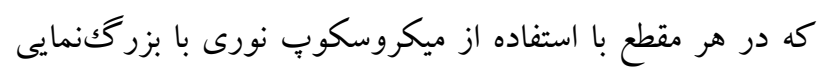

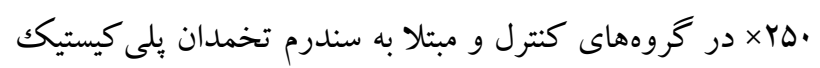
تغييرات ايجاد شده در بافت كبد به منظور تأييد ايجاد آسيب لئي

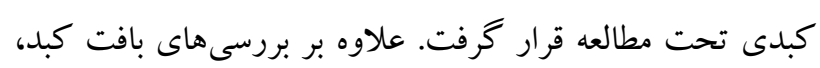
خون موشها نيز بهمنظور مطالعات سرولوزيكك برداشت شد. براى

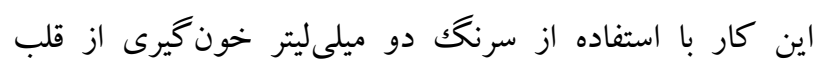
حيوانات انجام شد. لولههاى حاوى نمونهُ خون در بنمارى دماى

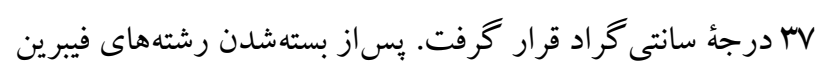

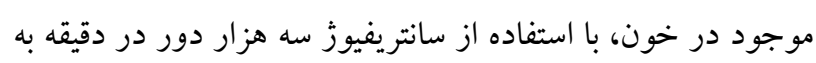
مدت ده دقيقه سرم نمونهاى خونى جدا شد و تا زمان انجام آزمايشهاى سرولوزيكك به منظور بررسى -Reactive Prot ein (CPR)

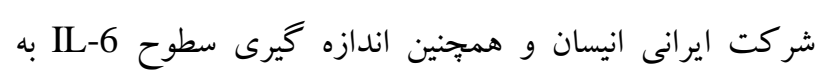
(Bender Medsystems, روش اليزا با استفاده از كيت اليزا Austria تجزيه و تحليل آمارى اطلاعات از نرمافزار INSTATE استفاده

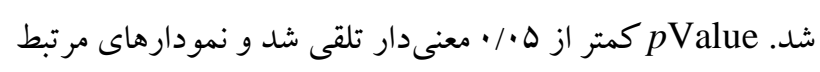
از طريق برنامه EXCEL رسم شد. اطلاعات ارائه شده بر حسب
كربنات با فضاى استاندارد و در محيط مناسب (درجه حرارت YF• ب درجة سانتى كراد و سيكل روشنايى و تاريكى r I ساعته) و دسترسى آزادانه به غذا (شركت خوراكك دام بهيرور- تهران) و آب در مركز تكثير و برورش حيوانات آزمايشگاهى دانشگاه خوارزمى نگهدارى شدند. بهمنظور القاى صحيح سندرم تخمدان يلى كيستيك موشها تحت بررسى اسمير وازينال قرار كرفتند و موشهايى انتخاب شدند كه داراى دو تا سه دوره استروس منظم در طى دوازده تا جهارده روز مشاهده اسمير وازينال بودند و در مرحله استروس سيكل توليد مثلى خود قرار داشتند. در اين تحقيق از تزريق تكك مرحلهاى و زير يوستى ب ميلى گرم بر كيلو گرم وزن بدن استراديول والرات (داروسازى ابوريحان- ايران) (n=32)

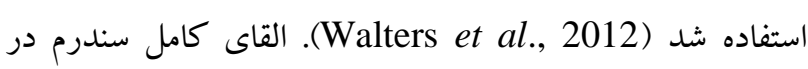
طول مدت هشت هفته بهواسطة نامنظم شدن سيكل استروس و وقوع فاز اسمير وازينال شاخى گيايدار (PVC) در اسميرهاى وازينالى، كه در اين مدت از حيوانات دو گروه و PCOS و كنترل تهيه شده بود، اثبات شد. بساز اطمينان از القاى كامل سندرم با

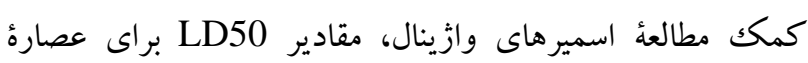
بركَ گزنه، كه بهصورت داخل وريدى به موشها تزريق شده بود،

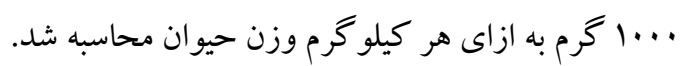

\section{روش تهيه عصارة ززنه}

براى تهيه عصاره كياه گزنه يساز جمع آورى گياه و تميز كردن آن، بهمدت دو هفته در سايه خشك شد. سيس به كمكك آسياب

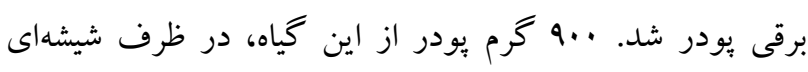
درب دارى ريخته و به ميزان مساوى اتانول 9ه درصد و آبمقطر اضافه شد و بهمدت جهار روز خيسانده شد. طى اين مدت بهطور متناوب محتويات ظرف با استفاده از همزن هم زده شد تا عصاره در الكل به طور كامل حل شود. سيس محلول صاف شد و عصاره

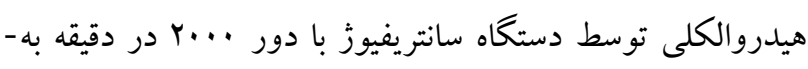
مدت · r دقيقه سانتريفيوز شد. مايع حاصل در ظروف درباز قرار داده شد تا الكل آن تبخير شود. سرانجام شيره سبز رنك غلئ غليظى بهدست آمد كه براى تغليظ بيشتر، عصاره در درجهُ حرارت .ه-

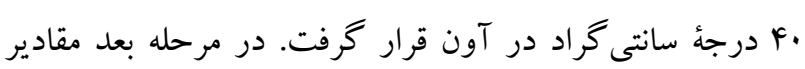
مورد نظر در آبمقطر حل شد تا اينكه غلظتهاى مختلف به دست آمد (Parvizpur et al., 2001). 
سيتو كينها علاوه بر ايجاد التهاب، در ايجاد اختلالاتى ازجمله آترواسكلروزيس، آرتريت روماتوئيد و ازجمله در ايجاد كبد جرب غير الكلى دخيل هستند) al., 2000 ). اينترلو كين -6 سلولهاى مختلفى ازجمله سلولهاى هي ايمنى، هياتوسيتها، سلولهاى بنيادى هماتوبوئيتيك و استئو كلاست ها را فعال مى كند. همجنين، اينترلو كين-6 داراى دامنه وسيعى از عملكردهاى مختلف شامل تحريك التهاب، تحريك ياسخ ايمنى و غيره است. باوجوداين، اينترلو كين -6 يكك فاكتور كليدى در باسخ مرحله حاد است، كه ازطريق دخالت در سنتز جندين يروتئين دخيل در فاز حاد مانند CRP و آميلوئيد A سرمى

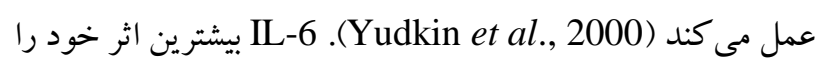
از طريق تأثير بر حساسيت به انسولين اعمال مى كند. نشان داده شده است كه سطوح سرمى IL-6 در مدلهاى حيوانى مبتلا به كبد جرب غيرالكلى بالاتر است (Haukeland et al., 2006). Wieckowska و همكاران (2008) نشان دادند كه در انسانهاى برى مبتلا به NASH، رابطه مثبتى بين بيان IL-6 در هياتوسيتها و Wieckowska et al., ) شدت كبد جرب غير الكلى وجود دارد 2008). IL-6 نقشهاى متضادى در كبد جرب ايفا مى كند. براى مثال، علاوه براينكه IL-6 مى تواند باعث بهبود آسيب كبدى شود، ممكن است باعث افزايش حساسيت كبد به آسيب، تحريك آبويتوز در هياتوسيتها، تحريك مقاومت به انسولين و مشاركت در ييشرفت NASH شود (Yamaguchi et al., 2010). در بيماران PCOS معمولاً جاقى، مقاومت به انسولين و هيبر انسولينميا و ديابت نوع r ديده مىشود (Sathyapalan et al., 2010) كه به نظر مىرسد با استدلالات زير نقش مهمى در ايجاد و تشديد علايم PCOS بازى مى كنند. CRP يكى از يروتئينهاى مهم التهاب است كه در واكنش به افزايش سطوح سايتوكينهاى التهابى مانند IL-6، IL18 و IL1 توسط كبد ترشح مىشود. غلظت بالاى CRP كه با افزايش خطر ابتلا به بيمارىهاى قلى عروقى نيز مرتبط است، در زنان مبتلا به PCOS مشاهده مىشود.

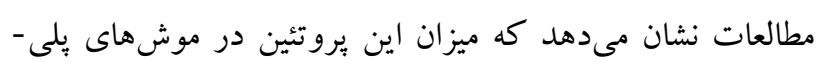
كيستيك القاشده با استراديول بهصورت معنىدارى بالا بوده است كه درون c-174g (Franks et al., 1995)
نتايج نتايج مورفومتريك رنك آنت آميزى هماتو كسيلين و ائوزين

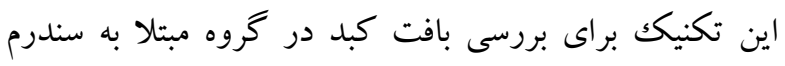

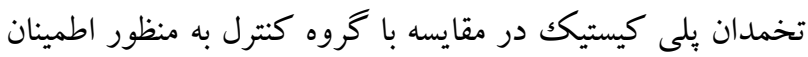
از وقوع آسيب كبدى انجام شد (شكل (). در اين مطالعه هارامترهاى مربوط به كبد موشهاى مبتلا به سندرم تخمدان يلى كيستيك تحت بررسى قرار گرفت كه براى اين منظور، فاكتور التهابى IL-6 به روش الايزا و همجينين سطوح خونى فاكتور CRP بروسى شد.

بررسى تغييرات بيان IL-6 به روش الايزا

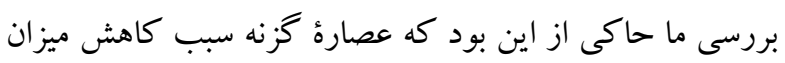

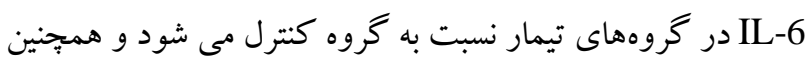

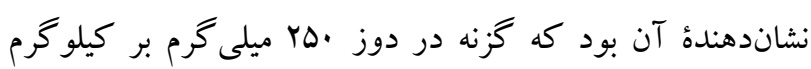
وزن بدن نسبت به دوزهاى ديخر مؤثرتر بوده است و اين

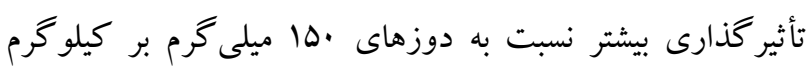

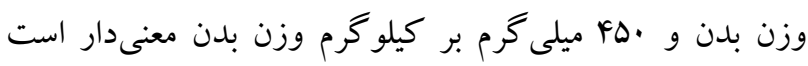

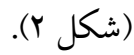

\section{بروسى تغييرات CRP}

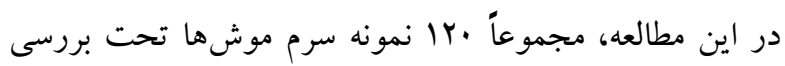
قرار گرفت. براساس نتايج بهدست آمده مشخص شد كه ميانخين نتايج حاصل از كيت آكلوتيناسيون اسلايدى انيسان در دو گروه موش هاى PCOS تيمار شده با غلظت هاى • 10 ميلى گرم گزنه به

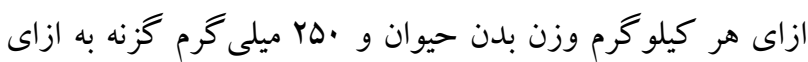
هر كيلو گرم وزن بدن حيوان مشابه با ميانگين حاصل از گروه وره كنترل داراى بِاسخ منفى بود كه اين پِاسخ نشاندهندهُ تأثير مثبت عصارة هيدروالكلى گياه گزنه بر كاهش ميزان CRP در خون اين موشها است. در مقابل، در گروه موش هاى PCOS تيمار شده با

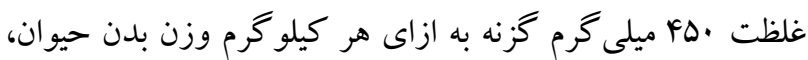
ميانگين نتايج حاصل از آزمايش مشابه نتايج حاصل از گروه موشهاى PCOS مثبت بود و مى توان اينطور نتيجه گيرى كرد كه عصاره گياه گزنه در اين غلظت تأثير جندانى در كاهش سطح سرمى اين فاكتور اعمال نكرده است. 

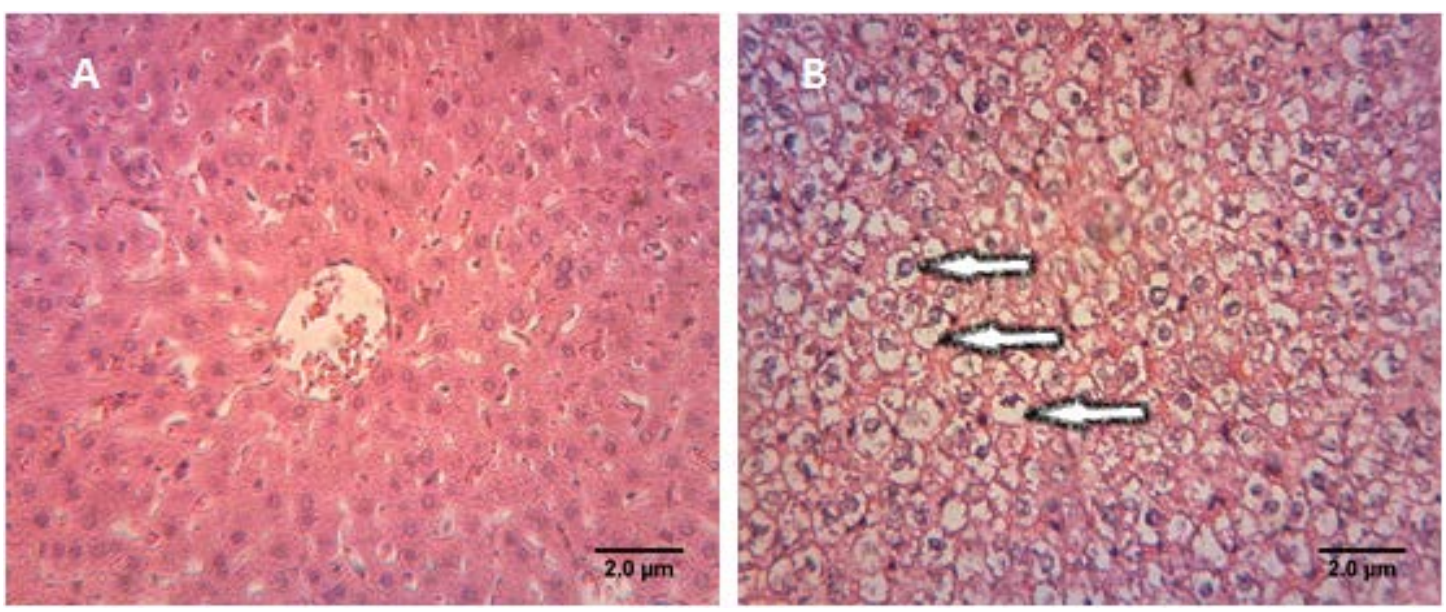

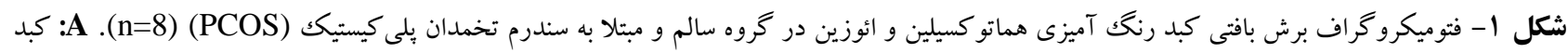

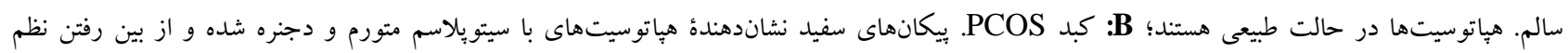

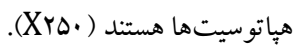

Fig. 1. Photomicrograph of healthy liver tissue slices in control and PCOS groups $(n=8)$. A: Control liver, hepatocytes are normally. B: PCOS liver. White arrows indicate degenerated hepatocytes with swollen cytoplasm compared to control groups. Hematoxylin and eosin staining (X250).

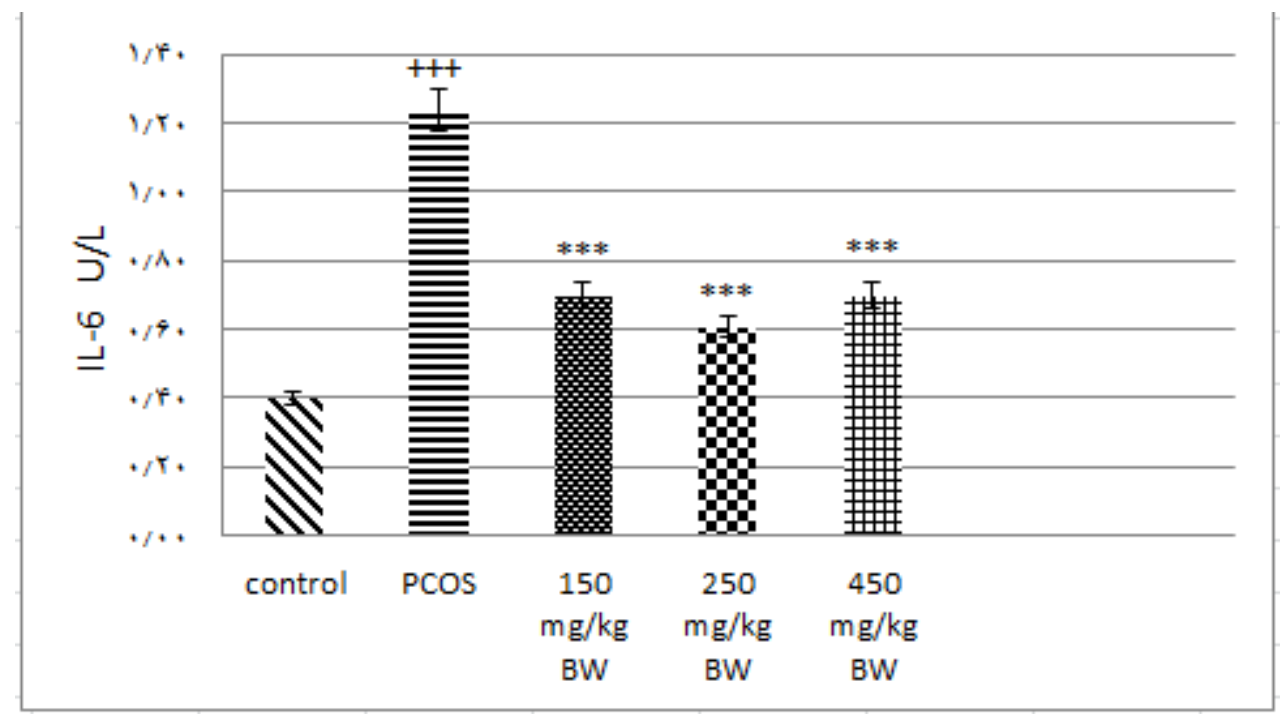

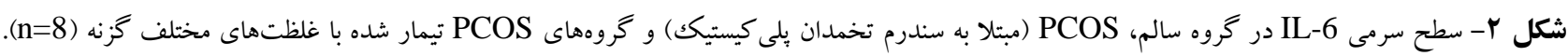

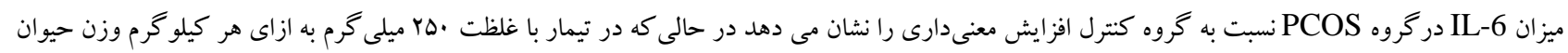

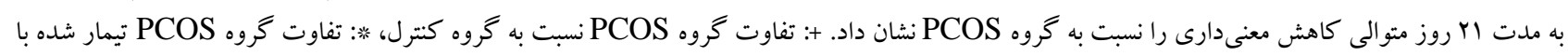

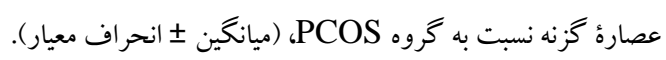

Fig. 2. Serum IL-6 concentration in control, PCOS and UD extract-treated PCOS groups $(n=8)$. Significant increases were observed in IL-6 in PCOS group compared with control group; While PCOS group treated with nettle extract at a concentration of $250 \mathrm{mg}$ per kg of body weight for 21 consecutive days, compared with PCOS and showed a significant decrease. +Differences PCOS group versus control group; *Differences PCOS group versus UD extract-treated PCOS groups; (Mean $\pm \mathrm{SD}$ ); ${ }^{+++} p<0.001 ;{ }^{* * *} \mathrm{P}<0.001$; PCOS. 
بيمارىهاى عفونى، كاهش علايم آرتريت و كاهش التهاب مفاصل استفاده شده است. در يك مطالعه in vitro در آلمان نشان

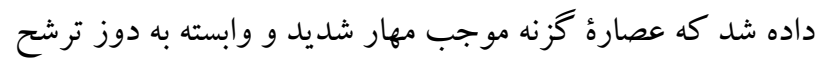
مى شود. همجنين نتايج بر رسى هاى ديخر نشان داد كافئك ماليك كه عمدهترين جزء فنولى گياه گزنه است سنتز سيكلواكسيزنازها را به صورت وابسته به دوز مهار مئى كند.

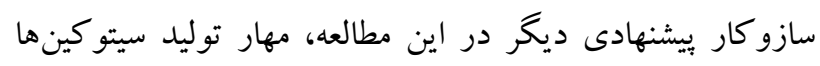

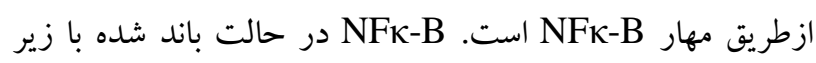
واحد مهارى IKB به شكل كميلكس غير فعال در سيتويلاسم وجود دارد و فسفريلاسيون اين زير واحد مهارى موجب تغيير

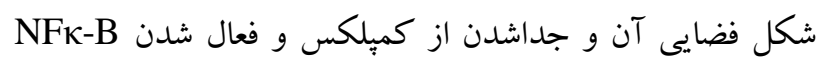

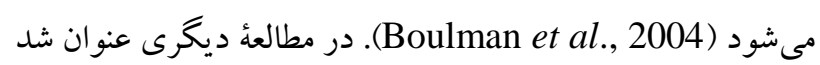

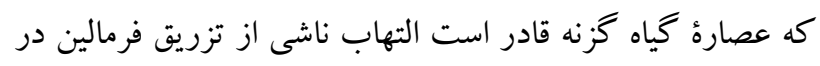

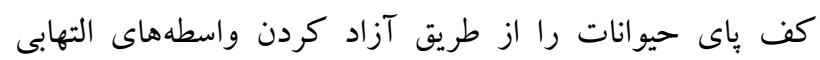
محيطى به طور مشخص كاهش دهد. در تأييد اين مطلب، مهار

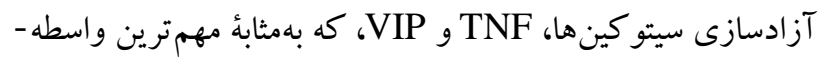

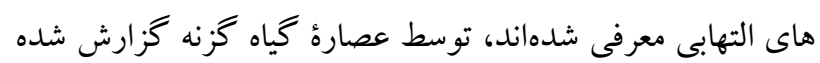

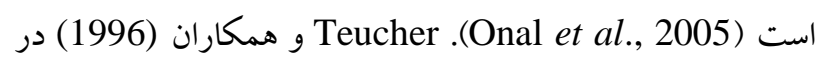

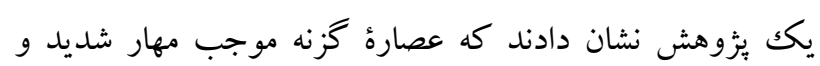

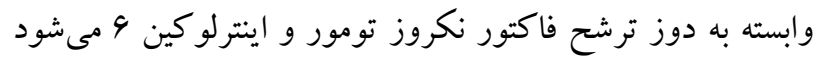

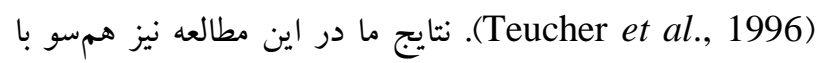

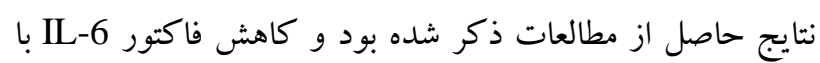
استفاده از آزمون الايزا، همجنين كاهش در مر سطوح

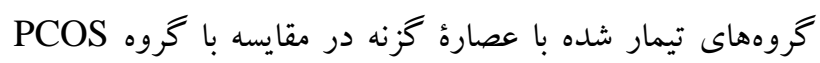

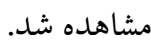

\section{نتيجه كيرى}

باتوجه به تأثير عصارة گياه گزنه بر كاهش فاكتورهاى التهابى و در نتيجه افزايش حساسيت به انسولين بهمنزله عوامل بهوجود آورنده مجموعه اختلالات سندرم متابوليك، و با توجه به اينكه

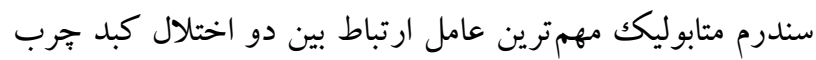

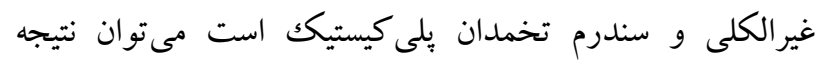

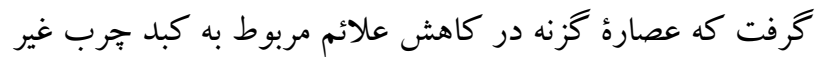
الكلى در موشهاى PCOS تيمار شده با عصاره خزنه مؤثر بوده
ناحئ بروموتور زن IL-6 قرار دارد و فعاليت بروموتور را تعديل

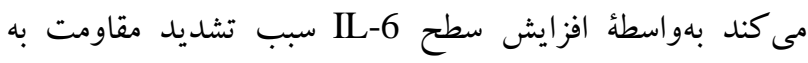
انسولين، جاقى و هيير آندروزنيسم مى شود كه علايم مشترك بين

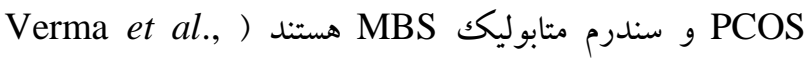
2006). IL-6 قابليت تحريك سلولهاى آدرنال انسانى را دارد و

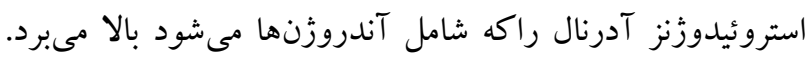
آندروزنها بهصورت غير مستقيم سبب هاييرتروفى اديبوسيتها

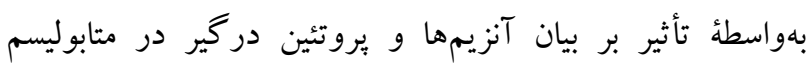
كربوهيدراتها و جربىها مىشود و در استرس اكسيداتيو و تمايز

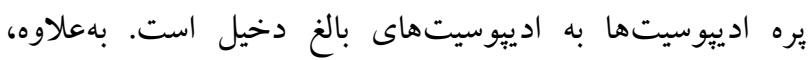

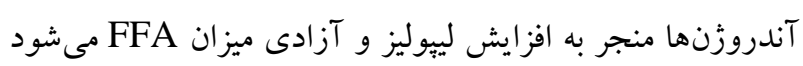

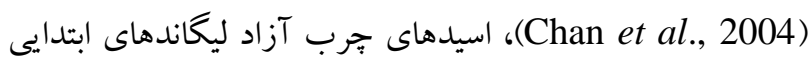
براى رسبتورهاى TOLL-LIKE هستند كه تنظيم كنندهاى مركزى رسبتورهاى ايمنى ذاتى هستند. آندروزنها با افزايش

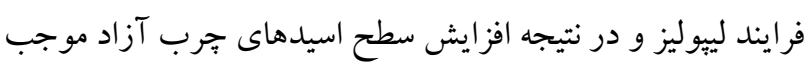

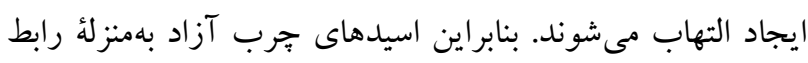

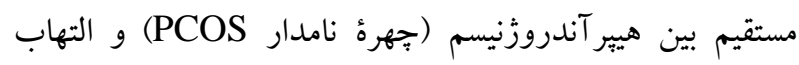

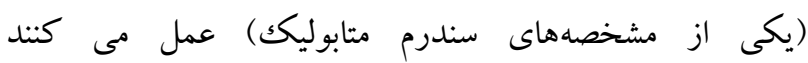
CRP .(Villuendas et al., 2002) ينتراكسىهاست كه بهمنزله حساسترين شاخص التهابى نقش

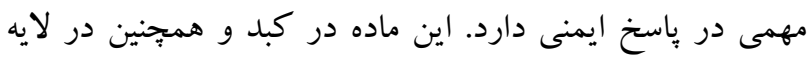

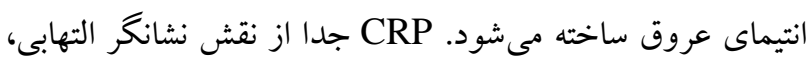
مىتواند با روشهاى مختلفى، ازجمله كاهش توليد نيتريك

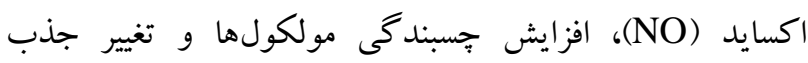

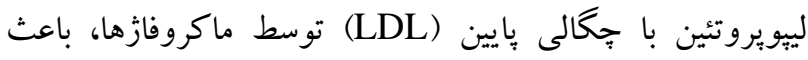
تخريب عروق شود. ميزان آن عمدتاً توسط برخى سايتو كينها به به بانه

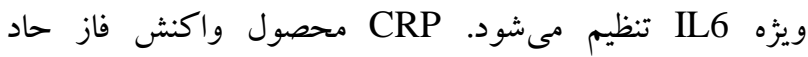

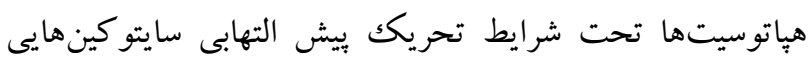
ازقبيل اينترلوكين و و فاكتور نكروز تومورى است. عصارؤ كياه كزنه توليد سايتو كين را متوقف مى كند، اما نحوهُ عملكرد آن آن

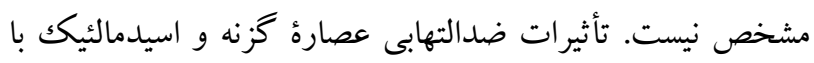

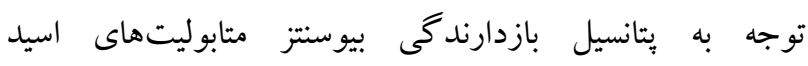

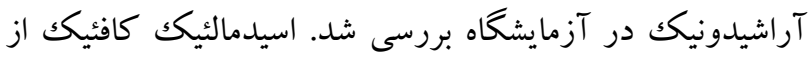

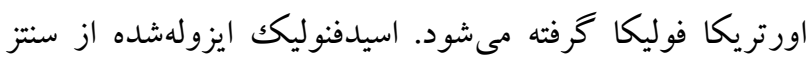

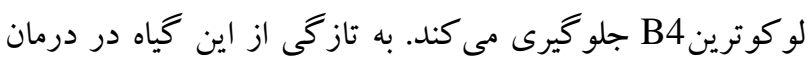




\section{REFERENCES}

Apridonidze, T., Essah, P.A., Iuorno, M.J. and Nestler, J.E. 20005. Prevalence and characteristics of the metabolic syndrome in women with polycystic ovary syndrome. - J. Clin. Endocrinol. Metabol. 90: 19291935.

Azziz, R., Carmina, E., Dewailly, D., Diamanti-Kandarakis, E., Escobar-Morreale, H.F. and Futterweit, W. 2006. Positions statement: criteria for defining polycystic ovary syndrome as a predominantly hyperandrogenic syndrome: an Androgen Excess Society guideline. - J. Clin. Endocrinol. Metabol. 91: 4237-4245.

Azziz, R., Woods, K.S., Reyna, R., Key, T.J., Knochenhauer, E.S. and Yildiz, B.O. 2004. The prevalence and features of the polycystic ovary syndrome in an unselected population. - J. Clin. Endocrinol. Metabol. 89: 2745-2749.

Boulman, N., Levy, Y., Leiba, R., Shachar, S., Linn, R. and Zinder, O. 2004. Increased C - reactive protein levels in the polycystic ovary syndrome: a marker of cardiovascular disease. - J. Clin. Endocrinol. Metab. 89: 2160-2165.

Brzozowska, M.M., Ostapowicz, G. and Weltman, M.D. 2009. An association between non-alcoholic fatty liver disease and polycystic ovarian syndrome. - J. Gastroenterol. Hepatol. 24: 243-247.

Cai, D., Yuan, M., Frantz, D.F., Melendez, P.A., Hansen, L., Lee, J. and Shoelson, S.E. 2005. Local and systemic insulin resistance resulting from hepatic activation of IKK-beta and NF-kappaB. - Nat. Med. 11: 183-190.

Carmina, E., Napoli, N., Longo, R.A., Rini, G.B. and Lobo, R.A. 2006. Metabolic syndrome in polycystic ovary syndrome (PCOS): lower prevalence in southern Italy than in the USA and the influence of the criteria for the diagnosis of PCOS. - Eur. J. Endocrinol. 154: 141-145.

Chan, D.F., Li, A.M., Chu, W.C., Chan, M.H., Wong, E.M., Liu, E.K., Chan, I.H., Yin, J., Lam, C.W., Fok, T.F. and Nelson, E.A. 2004. Hepatic steatosis in obese Chinese children. - Int. J. Obes. Relat. Metab. Disord. 28: 1257-1263.

Chang, R.J., Nakamura, R.M. and Judd, H.L. 1983. Insulin resistance in nonobese patients with polycystic ovarian disease. - J. Clin. Endocrinol. Metab. 57: 356359.

Dokras, A., Bochner, M., Hollinrake, E., Marklam, S., VanVoorhis, B. and Jagasia, D.H. 2005. Screening women with polycystic ovary syndrome for metabolic syndrome. - Obstet. Gynecol. 106: 131-137.

Edmison, J. and McCullough, A.J. 2007. Pathogenesis of non-alcoholic steatohepatitis: human data. - Clin. Liver Dis. 11: 75-104

Franks, S. 1995. Polycystic ovary syndrome. - N. Engl. J. Med. 333: 853-861.

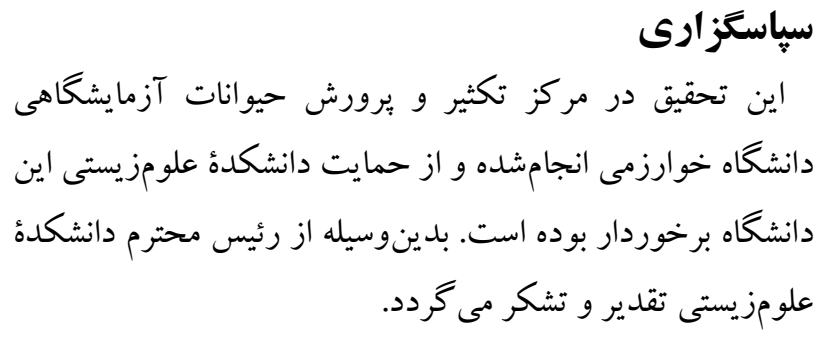


Haukeland, J.W., Damås, J.K., Konopski, Z., Løberg, E.M., Haaland, T., Goverud, I., Torjesen, P.A., Birkeland, K., Bjøro, K. and Aukrust, P. 2006. Systemic inflammation in nonalcoholic fatty liver disease is characterized by elevated levels of CCL2. - J. Hepatol. 44: 1167-1174.

James, A. and Duke. 2008. Phytochemical Databases, Beltsvilla Argriculture Research Center. - Green Farmacy Garden.

Janbakhsh, A., Mansouri, F., Vaziri, S., Sayad, B., Afsharian, M. and Rahimi, M. 2013. Effect of selenium on immune response against hepatitis $B$ vaccine with accelerated method in insulin-dependent diabetes mellitus patients. - Caspian J. Intern Med. 4: 603-606.

Klover, P.J., Clementi, A.H. and Mooney, R.A. 2005. Interleukin-6 depletion selectively improves hepatic insulin action in obesity. - Endocrinology. 146: 34173427.

Legro, R.S., Kunselman, A.R., Dodson, W.C. and Dunaif, A. 1999. Prevalence and predictors of risk for type 2 diabetes mellitus and impaired glucose tolerance in polycystic ovary syndrome: A prospective, controlled study in 254 affected women. - J. Clin. Endocrinol. Metabol. 84: 165-169.

Miller, A.M. and McInnes, I.B. 2011. Cytokines as therapeutic targets to reduce cardiovascular risk in chronic inflammation. - Curr. Pharm. Des. 17: 1-8.

Monfared, M., Kamkar, A., Ghaffari-Khaligh, S., Jebelli- Javan, A., Asadi, F. and Akhundzadeh-Basti, A. 2011. Antioxidative effects of Iranian Urtica dioica L. extracts on the oxidation of sunflower oil. - J. Med. Plants Res. 5: 4438-4445.

Onal, S., Timur, S., Okutucu, B. and Zihnioğlu, F. 2005. Inhibition of alpha-glucosidase by aqueous extracts of some potent antidiabetic medicinal herbs. Prep. Biochem. Biotechnol. 35: 29-36.

Parvizpur, A., Ahamadiani, A. and Kamalinejad, M. 2001. Probable role of purinergic system in antinociceptive effects of Trigonella foenumraecum leaves extract. - 14th International Congress of Geographic Medicine and 15th Iranian Congress of Physiology and Pharmacology. Shiraz- Iran. 5- 8: 346.

Sathyapalan, T. and A.S. 2010. Mediators of inflammation in polycystic ovary syndrome in relation to adiposity. - Mediators of Inflammation. doi: 10.1155/2010/758656.

Srikanthan, P., Korenman, S. and Davis, S. 2006. Polyciystic ovarian syndrome: the next cardiovascular dilemma in women? - Endocrinol. Metab. Clin. North Am. 35: 611-631.

Teucher, T., Obertreis, B., Ruttkowski, T. and Schmitz, H. 1996. Cytokine secretion in whole blood of healthy subjects following oral administration of Urtica dioica L. plant extract. - Arzneimittelfors-chung. 46: 906-910.

Tilg, H. and Diehl, A.M. 2000. Cytokines in alcoholic and nonalcoholic steatohepatitis. - N. Engl. J. Med. 343: 1467-1476.

Tracey, K.J. and Cerami, A. 1993. Tumor necrosis factor, other cytokines and disease. - Annu. Rev. Cell. Biol. 9: 317-343.
Verma, S., Devaraj, S. and Jialal, I. 2006. C Reactive protein promotes atherothrombosis. - Circulation. 113: 2135-2150.

Villuendas, G., San Millan, J.L., Sancho, J. and Escobar-Morreale, H.F. 2002. The 2597 G ! A and 2174 G ! C polymorphisms in the promoter of the IL-6 gene are associated with hyperandrogenism. - J. Clin. Endocrinol. Metabol. 87: 1134-1141.

Walters, K.A., Allan, C.M. and Handelsman, D.J. 2012. Rodent models for human polycystic ovary syndrome. - Biol. Reprod. 86: 1-12.

Wieckowska, A., Papouchado, B.G., Li, Z., Lopez, R., Zein, N.N. and Feldstein, A.E. 2008. Increased hepatic and circulating interleukin-6 levels in human nonalcoholic steatohepatitis. - Am. J. Gastroenterol. 103: 1372-1379.

Yamaguchi, K., Itoh, Y., Yokomizo, C., Nishimura, T., Niimi, T., Fujii, H., Okanoue, T. and Yosh-ikawa, T. 2010. Blockade of interleukin-6 signaling enhances hepatic steatosis but improves liver injury in methionine choline-deficient diet-fed mice. - Lab. Invest. 90: 1169-1178.

Yudkin, J.S., Kumari, M., Humphries, S.E. and Mohamed-Ali, V. 2000. Inflammation, obesity, stress and coronary heart disease: is interleukin-6 the link? Atherosclerosis. 148: 209-214.

\section{$* * * * *$}

How to cite this article:

Tayanloo, A., Zare, S., Karimzadeh-Bardei, L. and Hoseini, S. 2017. Effect of Urtica dioica hydroalcoholic extract on liver inflammatory factors in polycystic ovarian syndrome induced in Wistar rats by estradiol valerate. - Nova Biologica Rep. 4: 181-188.

$$
\begin{aligned}
& \text { تايانلو، ا.، زارع، ص.، كريمزاده باردئى، ل. و حسينى، س. وه؟1. بررسى }
\end{aligned}
$$

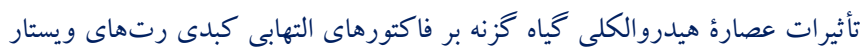

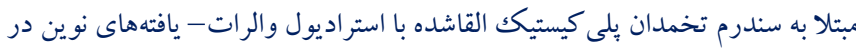

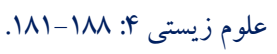

